\title{
Utilization of serum procalcitonin as a biomarker in the diagnosis and treatment of children with bacterial hospital-acquired pneumonia
}

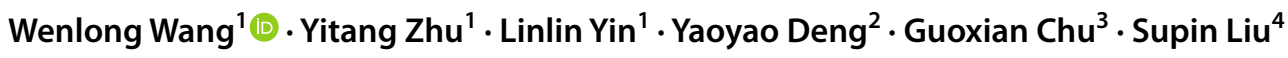

Received: 10 June 2020 / Accepted: 2 September 2020 / Published online: 29 September 2020

(c) Springer Science+Business Media, LLC, part of Springer Nature 2020

\begin{abstract}
Hospital-acquired pneumonia (HAP) is one of the common infections in hospitalized patients. Early and prompt diagnosis of HAP is important because it aids in the appropriate selection of antibiotics and decreases the mortality and morbidity of patients. The investigation on serum procalcitonin (PCT) levels in pediatric patients is limited. Herein we aimed to evaluate the role of PCT in the early diagnosis of children with bacterial HAP. The study enrolled 264 children ( $<14$ years old) who were radiographically detected by pulmonary condensation chest X-rays. The HAP patients were stratified by patterns of microbiological detection of pathogens. Baseline white blood cell (WBC) count, neutrophil proportion, PCT, and C-reactive protein (CRP) were measured on admission. The laboratory findings and microbiological findings were analyzed and compared among groups. The median PCT concentration of patients with typical bacterial pathogens $(3.95 \pm 3.75 \mathrm{ng} / \mathrm{mL})$ was significantly higher than the one of the patients with other pathogen types (median lower than $1.20 \mathrm{ng} / \mathrm{mL}$ ). Correlation analysis indicated a significant correlation between PCT concentrations and the main inflammation makers including WBC count, neutrophil proportion, and CRP. PCT level was significantly decreased to $0.86 \pm 1.46 \mathrm{ng} / \mathrm{mL}$ in post-treatment patients $(p<0.001)$. This cohort study with 264 pediatric HAP patients demonstrated the reliability of PCT level as a biomarker in patients with typical bacterial pathogens. Specifically, PCT cutoffs of $2 \mathrm{ng} / \mathrm{mL}$ accurately identified HAP children with typical bacterial pathogens. This finding suggested that PCT may serve as a reliable biomarker for the early diagnosis and treatment indicator of children with HAP.
\end{abstract}

Keywords Procalcitonin (PCT) · Hospital-acquired pneumonia (HAP) · Biomarker · Typical bacterial pathogens · C-reactive protein

Wenlong Wang

Wangwenlong07@126.com

1 Department of Clinical Laboratory, Cangzhou Central Hospital, No.16 Xinhua West Road, Cangzhou 061001, Hebei, China

2 Clinical Laboratory, Mengcun Hui Autonomous County Hospital, Chaoyang Dajie, Mengcun Hui Autonomous County, Cangzhou 061400, Hebei, China

3 Clinical Laboratory, People's Hospital of Qingxian, Nanhuanxi Road, Qingxian, Cangzhou 062650, Hebei, China

4 Department of Blood Collection Center, Cangzhou Central Hospital, No.16 Xinhua West Road, Cangzhou 061001, Hebei, China

\section{Introduction}

Hospital-acquired pneumonia (HAP) is one of the common infections in hospitalized patients, referring to pneumonia occurring as early as $48 \mathrm{~h}$ after hospital admission [1]. HAP is caused by individual or simultaneous infection with bacteria, viruses, or other types of pathogens, which require different treatment methods correspondingly [2]. Early and prompt diagnosis of HAP is important because it aids in the appropriate selection of antibiotics and decreases the morbidity and mortality of patients [3]. For pneumonia caused by bacteria, culture-based methods are the most common method for identifying the pathogens. The potential benefits of blood culture could be helpful to narrow the antibiotic spectrum, predict outcomes, and inform assessments of vaccine efficacy [4]. However, the impact of blood cultures has not been adequately studied. For instance, in a meta-analysis of smaller studies that enrolled with 3235 
community-acquired pneumonia (CAP) patients, only 12 patients $(0.4 \%)$ had positive results of blood culture [5]. Thus, although recommended by the Pediatric Infectious Diseases Society (PIDS) guidelines for most hospitalized children, routine blood cultures in children hospitalized with pneumonia are not enough for the accurate diagnosis of pneumonia.

Procalcitonin (PCT) is secreted by different types of cells from numerous organs in response to pro-inflammatory stimulation [6]. PCT has received approval from the Food and Drug Administration (FDA) of the United States as a diagnostic aid for sepsis in 2005 [7]. Clinically, a PCT concentration larger than $0.1 \mathrm{ng} / \mathrm{mL}$ indicates a bacterial infection that requires antibiotic treatment [8], while a PCT concentration higher than $0.5 \mathrm{ng} / \mathrm{mL}$ indicates the risk of severe sepsis or septic shock of patients [9]. In recent years, PCT has been considered as a specific and early biomarker for the diagnosis of systemic bacterial infection [10]. A recent study with 56 children with severe pneumonia showed that PCT level of patients in bacterial pneumonia group was significantly higher compared to the patients in the control group and non-bacterial pneumonia group [11]. However, the PCT level on patients suffering chronic non-specific inflammation, virus infection, autoimmune diseases, tumorous fever, and operative wounds would not increase significantly [12]. Using PCT as an indicator, reduced antibiotic exposure was achieved during the treatment for respiratory tract infections in adults [13].

In accordance with these previous reports, the PCT levels may be useful to predict bacterial HAP. To determine the value of serum PCT as an early marker for HAP, we enrolled over two hundred of pediatric patients and analyzed the clinical characteristics with laboratory findings and microbiological findings to evaluate the reliability of PCT in the early diagnosis of children with bacterial HAP, providing foundation and guidance for the antibiotic prescription selection.

\section{Materials and methods}

\section{Patients}

Two hundred and sixty-four (264) pediatric patients, who were hospitalized due to severe pneumonia in Cangzhou Central Hospital between October 2017 and January 2019, were enrolled in this study. The protocol was reviewed by the Institutional Review Board and the Ethics Committee of the Cangzhou Central Hospital. Informed consents were signed by the parents or guardians of each participant. The inclusion criterion for age is younger than 14 years. Hospital-acquired pneumonia (HAP) was determined by the presence of symptoms and signs including fever and respiratory system disorder. In addition, the patients were radiographically checked by chest X-rays for pulmonary condensation. Clinical data were retrieved from the electronic records of patients.

\section{Laboratory tests}

The HAP patients were stratified by patterns of microbiological detection of pathogens. Specifically, etiology was classified as four categories: typical bacterial pathogens with the detection of Streptococcus pneumoniae by routine sputum culture; atypical typical bacterial pathogens with the detection of Mycoplasma pneumoniae by serologic investigation; viral pathogens only detected by respiratory viruses and diagnostic testing using Respiratory Viruses and Diagnostic Testing (Luminex, Shanghai, China), which include the following: human metapneumovirus, adenovirus, coronavirus HKU1, 229E, OC43 and NL63, influenza A and B, parainfluenza viruses $1-4$, human rhinovirus, and respiratory syncytial virus.; no pathogen detected by these described methods.

Whole blood was collected from the patients, and white blood cell (WBC) count was determined by flow cytometry (Beckman Coulter, CA, USA) within $3 \mathrm{~h}$. The serum was separated and stored at $-20{ }^{\circ} \mathrm{C}$ for subsequent biomarker analysis. Specifically, serum C-reactive protein (CRP) was assessed by a nephelometric method (Dadebehring BN prospec 100 , Germany), and serum concentration of procalcitonin (PCT) was assayed by an enzyme-linked fluorescence assay (Wuhan Easydiagnosis Biomedicine Co. Ltd, Wuhan, China). PCT results were also detected after the treatment and compared with pre-treatment.

\section{Statistical analysis}

Data in this study were analyzed by statistical software SPSS 16.0. Variables were expressed as mean \pm standard deviation (SD). Clinical characteristics and laboratory test results were assessed by the application of analysis of variance, chisquare test when appropriate. Correlation analysis between PCT and the main inflammation markers were conducted by non-parametric Spearman's test. Statistical significance was considered when $p$ value is smaller than 0.05 .

\section{Results}

\section{Demographics and clinical characteristics of patients}

Demographics and clinical characteristics of patients are shown in Table 1. There were 264 children enrolled in this study, out of whom 128 are boys $(48.5 \%)$. There were 64 children $(24.2 \%)$ aged $<1$ year, 146 children aged $1-12$ years $(55.3 \%)$, and 54 children aged 13 years 
Table 1 Baseline characteristics

\begin{tabular}{ll}
\hline Characteristics & $n(\%)$ \\
\hline Number of patients & 264 \\
Gender, Boys & $128(48.5 \%)$ \\
Age, year (median) & 3.2 \\
$<1$ & $64(24.2 \%)$ \\
$1-12$ & $146(55.3 \%)$ \\
$13-14$ & $54(20.5 \%)$ \\
Length of hospital stay, $\geq 10$ days & $178(67.4 \%)$ \\
Admission to Intensive Care Unit & $183(69.3 \%)$ \\
Ventilator-associated pneumonia & $186(70.5 \%)$ \\
Microbiological findings & \\
Typical bacterial pathogens* & $56(21.2 \%)$ \\
Atypical bacterial pathogens* & $72(27.3 \%)$ \\
Viral pathogens only & $108(40.9 \%)$ \\
No pathogen detected & $28(10.6 \%)$ \\
Underlying diseases & \\
Neuromuscular diseases & $121(45.8 \%)$ \\
Gastrointestinal diseases & $83(31.4 \%)$ \\
Anatomical abnormalities in respiratory system & $62(23.5 \%)$ \\
Patients with immunosuppressive agents & $70(26.5 \%)$ \\
Chromosomal abnormalities & $51(19.3 \%)$ \\
Heart diseases & $46(17.4 \%)$ \\
Metabolic diseases & $48(18.2 \%)$ \\
Others & $67(25.4 \%)$ \\
\hline
\end{tabular}

*Includes bacterial detections with and without viral codetection

\#The viruses tested for this study included the following: adenovirus, coronavirus HKU1, 229E, OC43 and NL63, influenza A and B, human metapneumovirus, parainfluenza viruses $1-4$, human rhinovirus, and respiratory syncytial virus

(20.5\%). Among all the patients, 178 of them (67.4\%) had larger than 10 days of hospital stay, 183 (69.3\%) of them were admitted to the Intensive Care Unit, and 186 of them (70.55) had ventilator-associated pneumonia due to severe outcomes.
Microbiological findings showed that children included in this study were detected at a higher percentage for viral pathogen $(108,40.9 \%)$, while 56 children $(21.2 \%)$ had typical bacterial pathogens, 72 children (27.3\%) had atypical bacterial pathogen, and 28 children (10.6\%) had no pathogen detected.

We also detected the underlying diseases of these patients, and the records showed that 121 children (45.8\%) with neuromuscular diseases, 83 children (31.4\%) with gastrointestinal diseases, 62 children $(23.5 \%)$ with anatomical abnormalities in the respiratory system, 70 patients $(26.5 \%)$ with immunosuppressive agents, 51 patients (19.3\%) with chromosomal abnormalities, 46 patients (17.4\%) with heart diseases, 48 patients (18.2\%) with metabolic diseases, and $67(25.4 \%)$ with other diseases.

\section{Laboratory findings among patients with different pathogens}

As shown in Table 2, the median WBC count $\left(\times 10^{3} / \mu \mathrm{L}\right)$ of the total patients was $11.66 \pm 4.48$, and there was no significant difference among patients in the four categories divided by pathogens. The median neutrophil proportion (\%) of all participated patients was $61.9 \pm 16.29$, and there was no difference observed among pathogen-based groups. The median CRP of all patients was $3.22 \pm 2.22 \mathrm{mg} / \mathrm{dL}$, without significant difference among all four categories. Interestingly, the median PCT concentration of patients with typical bacterial pathogens $(3.95 \pm 3.75 \mathrm{ng} / \mathrm{mL})$ was significantly higher than the one of the patients with atypical bacterial pathogens $(0.63 \pm 1.53 \mathrm{ng} / \mathrm{mL}, p<0.001)$, the patients with viral pathogens only $(1.07 \pm 1.69 \mathrm{ng} / \mathrm{mL}, p<0.001)$, as well as the patients with no pathogen detected $(1.18 \pm 1.68 \mathrm{ng} /$ $\mathrm{mL}, p<0.01$ ). Further box plot (Fig. 1) showed that the PCT levels were higher in patients with typical bacterial pathogens (IQR, 0.84-12) when compared to those with atypical bacterial pathogens (IQR, 0.06-8.8), viral pathogens only

Table 2 Comparison of laboratory findings among patients with different pathogens

\begin{tabular}{lccccc}
\hline Characteristic & Total $(n=264)$ & $\begin{array}{l}\text { Typical bacterial } \\
\text { pathogens* }(n=56)\end{array}$ & $\begin{array}{l}\text { Atypical bacterial } \\
\text { pathogens* }(n=72)\end{array}$ & $\begin{array}{l}\text { Viral pathogens } \\
\text { only }{ }^{\#}(n=108)\end{array}$ & $\begin{array}{l}\text { No patho- } \\
\text { gen detected } \\
(n=28)\end{array}$ \\
\hline WBC $\left(\times 10^{3} / \mu \mathrm{L}\right)$ & $11.66 \pm 4.48$ & $11.92 \pm 4.02$ & $11.63 \pm 4.56$ & $12.74 \pm 4.38$ & $10.34 \pm 4.96$ \\
Neutrophil proportion $(\%)$ & $61.9 \pm 16.29$ & $67.06 \pm 15.68$ & $64.35 \pm 14.73$ & $56.25 \pm 16.78$ & $59.94 \pm 17.96$ \\
CRP $(\mathrm{mg} / \mathrm{dL})$ & $3.22 \pm 2.22$ & $3.05 \pm 2.35$ & $3.17 \pm 2.11$ & $3.31 \pm 1.96$ & $3.36 \pm 2.46$ \\
PCT $(\mathrm{ng} / \mathrm{mL})$ & $1.57 \pm 2.57$ & $3.95 \pm 3.75$ & $0.63 \pm 1.53^{\text {aaa }}$ & $1.07 \pm 1.69^{\text {aaa }}$ & $1.18 \pm 1.68^{\text {aa }}$ \\
\hline
\end{tabular}

$W B C$ white blood cell count, $C R P$ C-reactive protein, $P C T$ procalcitonin

*Includes bacterial detections with and without viral codetection

\#The viruses tested for this study included the following: adenovirus, coronavirus HKU1, 229E, OC43 and NL63, influenza A and B, human metapneumovirus, parainfluenza viruses $1-4$, human rhinovirus, and respiratory syncytial virus

Data are presented as mean \pm SD. ${ }^{\text {aa }} P<0.01,{ }^{\text {aaa }} p<0.001$ compared to typical bacterial pathogens 


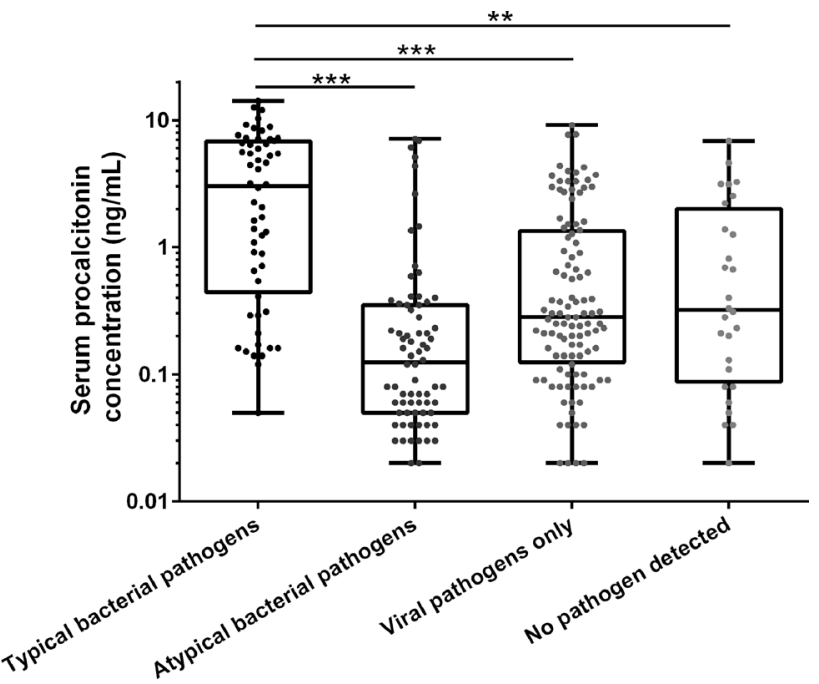

Fig. 1 Serum procalcitonin concentrations among children with hospital-acquired pneumonia stratified by patterns of microbiological detection. Box plot with all data are used to present the data. Note that the $y$-axis is presented in $\log (10)$ scale. ${ }^{*} P<<0.01, * * * p<0.001$ compared to typical bacterial pathogens

Table 3 Correlation analysis between serum PCT and the main markers of inflammation

\begin{tabular}{llr}
\hline & \multicolumn{2}{l}{ PCT $(\mathrm{ng} / \mathrm{mL})$} \\
\cline { 2 - 3 } & $r$ & $p$ \\
\hline WBC $\left(\times 10^{3} / \mu \mathrm{L}\right)$ & 0.412 & $<0.001$ \\
Neutrophil proportion $(\%)$ & 0.341 & $<0.001$ \\
CRP $(\mathrm{mg} / \mathrm{dL})$ & 0.224 & 0.004 \\
\hline
\end{tabular}

$W B C$ white blood cell count, $C R P$ C-reactive protein, $P C T$ procalcitonin
(IQR, 0.12-8.6), or no pathogen detected (IQR, 0.10-8.3). PCT level were similar in children with detected viral pathogens compared with children without detected pathogen.

\section{Correlation between serum PCT and inflammation markers}

As s specific and early marker for systemic inflammation, PCT was compared with other traditional systematic inflammation markers in our study. Correlation analysis indicated significant correlation between serum PCT concentrations and the main inflammation makers. As seen in Table 3, $r=0.412, p<0.001$ for WBC, $r=0.341, p<0.001$ for neutrophil proportion, and $r=0.224, p=0.004$ for CRP, respectively.

\section{Stratified analysis of PCT levels among patients with different pathogens}

Stratified analysis of PCT levels was also performed to determine correlation between the PCT level and pathogens. As shown in Table 4, among 60 children (22.7\% of cohort) with PCT concentrations $<0.1 \mathrm{ng} / \mathrm{mL}$, only 1 patient had a typical bacterial pathogen detected. Among the patients with a PCT concentration ranging from 0.1 to $<1.99 \mathrm{ng} / \mathrm{mL}$, only 4-9 children had a typical bacterial pathogen detected (7.1\%-16.1\%). In contrast, among 66 children (23.1\%) with a PCT concentration $\geq 2 \mathrm{ng} / \mathrm{mL}, 32$ children $(57.2 \%)$ had typical bacterial pathogen detected, which was significantly higher than the numbers of children with atypical bacteria detected $(6,8.3 \%)$, children with viral pathogens $(21$, $19.4 \%)$, and children without detected pathogen $(7,25 \%)$.

\section{PCT concentrations before and after treatment}

To further evaluate the specificity of PCT as a marker in HAP, we compared the serum PCT level on patients before
Table 4 Comparison of serum procalcitonin concentration ranges among patients with different pathogens

\begin{tabular}{llllll}
\hline $\begin{array}{l}\text { PCT Range } \\
(\mathrm{ng} / \mathrm{mL})\end{array}$ & Total $(n=264)$ & $\begin{array}{l}\text { Typical bacte- } \\
\text { rial pathogens } \\
(n=56)\end{array}$ & $\begin{array}{l}\text { Atypical bacte- } \\
\text { rial pathogens* } \\
(n=72)\end{array}$ & $\begin{array}{l}\text { Viral pathogens } \\
\text { only }^{\#}(n=108)\end{array}$ & $\begin{array}{l}\text { No patho- } \\
\text { gen detected } \\
(n=28)\end{array}$ \\
\hline$<0.1$ & $60(22.7 \%)$ & $1(1.8 \%)$ & $34(47.2 \%)$ & $22(20.4 \%)$ & $7(25 \%)$ \\
$0.1-0.24$ & $63(23.9 \%)$ & $9(16.1 \%)$ & $17(23.6 \%)$ & $29(26.9 \%)$ & $5(17.9 \%)$ \\
$0.25-0.49$ & $37(14.0 \%)$ & $4(7.1 \%)$ & $10(13.9 \%)$ & $17(15.7 \%)$ & $4(14.3 \%)$ \\
$0.5-0.99$ & $22(8.3 \%)$ & $5(8.9 \%)$ & $3(4.2 \%)$ & $10(9.3 \%)$ & $3(10.7 \%)$ \\
$1-1.99$ & $21(8.0 \%)$ & $5(8.9 \%)$ & $2(2.8 \%)$ & $9(8.3 \%)$ & $2(7.1 \%)$ \\
$\geq 2$ & $61(23.1 \%)$ & $32(57.2 \%)$ & $6(8.3 \%)$ & $21(19.4 \%)$ & $7(25 \%)$ \\
\hline
\end{tabular}

PCT procalcitonin

*Includes bacterial detections with and without viral codetection

\#The viruses tested for this study included the following: adenovirus, coronavirus HKU1, 229E, OC43 and NL63, influenza A and B, human metapneumovirus, parainfluenza viruses 1-4, human rhinovirus, and respiratory syncytial virus 
Table 5 Serum procalcitonin concentration detection results of patients with different pathogens before and after treatment

\begin{tabular}{lrll}
\hline Group & $n$ & PCT $(\mathrm{ng} / \mathrm{mL})$ & \\
\cline { 3 - 4 } & & Pre-treatment & Post-treatment \\
\hline Total & 264 & $1.57 \pm 2.57$ & $0.95 \pm 1.53$ \\
Typical bacterial pathogens* & 56 & $3.95 \pm 3.75$ & $0.86 \pm 1.46^{\text {aaa }}$ \\
Atypical bacterial pathogens* & 72 & $0.63 \pm 1.53$ & $0.78 \pm 1.68$ \\
Viral pathogens only & 108 & $1.07 \pm 1.69$ & $0.91 \pm 1.45$ \\
No pathogen detected & 28 & $1.18 \pm 1.68$ & $1.23 \pm 1.73$ \\
\hline
\end{tabular}

PCT procalcitonin

*Includes bacterial detections with and without viral codetection

\# The viruses tested for this study included the following: adenovirus, coronavirus HKU1, 229E, OC43 and NL63, influenza A and B, human metapneumovirus, parainfluenza viruses $1-4$, human rhinovirus, and respiratory syncytial virus

Data are presented as mean \pm SD. ${ }^{\text {aaa }} P<0.001$ compared to pre-treatment

and after treatment. As demonstrated in Table 5, the PCT level of pre-treatment patients as a whole was $1.57 \pm 2.57 \mathrm{ng} /$ $\mathrm{mL}$, which was higher than the one of post-treatment patients $(0.95 \pm 1.53 \mathrm{ng} / \mathrm{mL})$. Strikingly, PCT levels in patients with typical bacterial pathogens changed from $3.95 \pm 3.75 \mathrm{ng} /$ $\mathrm{mL}$ in pre-treatment patients to $0.86 \pm 1.46 \mathrm{ng} / \mathrm{mL}$ in posttreatment patients $(p<0.001)$, indicating the significant reliability of this marker.

\section{Discussion}

The goal of the study is to use procalcitonin as an early indicator to distinguish between bacterial infections and viral infections of children HAP. There were 264 pediatric patients younger than 13 years old enrolled in our study. Our analysis clearly demonstrated that the serum PCT concentration in patients with typical bacterial pathogens was significantly higher than the one of patients with other pathogen types. In addition, the concentration of PCT was significantly decreased after the treatment of HAP with typical bacterial pathogens. These results showed that PCT can be included in the treatment algorithms for pediatric patients with HAP as a reliable diagnosis and treatment biomarker.

A great number of studies on HAP have been performed in ICU patients, and mechanical ventilation used there could be a major risk factor for nosocomial pneumonia [14]. In our study, we checked these severe outcomes, and the baseline characteristics of patients showed that $69.3 \%$ of the patients were admitted to ICUs, and $70.5 \%$ of patients were ventilator-associated pneumonia. These data indicated the high percentage of the risk of HAP, which requires the development of a more accurate and reliable diagnosis biomarker. In addition, some studies revealed that serum PCT level increased dependently with the severity of the diseases in cases of severe invasive bacterial CAP [15], so it is not difficult to understand the PCT level in all HAP patients as a whole was $1.57 \mathrm{ng} / \mathrm{mL}$, much higher than the plasma levels of PCT in healthy individuals $(0.1 \mathrm{ng} / \mathrm{mL})$, the concentration of which was extremely low, and could hardly be detected during physiological conditions [16]. Speaking of the pneumonia severity, it would be interesting to run a multivariate logistic regression model to see if PCT could serve as an independent predictor of pneumonia severity, by comparing with the consolidation extent on chest $\mathrm{x}$-rays in future studies.

Blood cultures were collected from all patients and bacterial sputum cultures were observed for $48.5 \%$ of the patients, while viruses were detected in 108 (42\%) of children's blood samples. Streptococcus pneumoniae test was positive in $56(21.2 \%)$ of all samples. A significant association was observed between microbiological findings and PCT levels. PCT has a different profile than other presently used markers of pneumonia, such as WBC count, neutrophil proportion, and CRP. Clinically, the combination of the WBC count and the CRP level is commonly used as a basis to determine infection [17]. CRP is associated with nonspecific inflammatory, which rapidly increased upon trauma, serving as a marker of acute inflammation. In this study, we found increased levels of CRP in all inflammatory conditions associated with various pathogen types. Therefore, CRP is of limited value in distinguishing infection caused by different pathogens. Contrary to this, the PCT level remains unchanged or increases only modestly in patients infected by respiratory viruses [18]. In addition, serum PCT is detectable as early as $3-4 \mathrm{~h}$ after the bacterial invasion, which is much sensitive than the change of CRP level [19]. Consistently, we saw a significantly higher concentration of PCT in patients with typical bacterial pathogens, while the values of WBC count, neutrophil proportion, and CRP were similar among different patient groups categorized by pathogens. To be noted, we did not include a group with combined bacterial and viral pathogens, given the slight increase contributed by a viral infection. Our results displayed the correlation between PCT and the traditional inflammatory markers including WBC, neutrophils, and CRP, with its distinctive value.

A previous study that used PCT as an important biomarker for the distinction of bacterial and non-bacterial pneumonia of children showed that the value of PCT in the pretreated bacterial pneumonia group was $12 \mu \mathrm{g} / \mathrm{L}$ [11], which was much higher than the value measured in our study $(3.95 \mu \mathrm{g} / \mathrm{L})$. Korppi et al. found no differences in PCT values between pneumococcal and other etiology infections in pediatric pneumonia [20], which was later stated that only PCT with $\geq 1 \mathrm{ng} / \mathrm{mL}$ cut-off was a reliable marker of bacterial CAP [21]. Further, Toikka et al. described that PCT 
concentrations with high cut-off ( $>2 \mathrm{ng} / \mathrm{mL}$ ) were positively associated with the bacterial etiology of CAP and PCT values in children [22]. Given the discrepancy of PCT levels in different assays, as well as the lack of defined cut-off value of PCT in relation to pediatric pneumonia, we stratified the PCT range into $<0.1,0.1-0.24,0.25-0.49,0.5-0.99,1-1.99$, and $2 \mathrm{ng} / \mathrm{mL}$. Our results showed the positive results of the PCT indicator. Specifically, patients with typical bacterial pathogens took up to $57.2 \%$ of the patients with PCT values larger than $2 \mathrm{ng} / \mathrm{mL}$.

Compared to other earlier studies that used bacterial serology or blood culture for the diagnosis of pediatric pneumonia, or studies that used PCT assay that has relatively lower detection limits, our study successfully detected PCT concentrations in a wider range, and thus atypical and viral pneumonia can be distinguished from typical bacterial pneumonia [23]. To date, in spite of multiple pieces of evidence supporting the diagnostic and prognostic values for PCT, many studies have reported various prognostic factors for inflammatory diseases in adults or elderly patients [24-26]. However, only a few studies have assessed the role of PCT as a prognostic factor in pediatric pneumonia patients. Our study evaluated the predictive value of PCT with several strengths, including the enrollment of children cohort, comprehensive diagnostic testing, and stratified analysis of results. In addition to the value in HAP etiology, PCT can be also used as a biomarker in the evaluation of HAP treatment, which can potentially lower the hospital stay and antibiotic duration.

\section{Conclusion}

In conclusion, in this cohort of 264 subjects, the serum PCT concentration in patients with typical bacterial pathogens was significantly higher than the one of patients with atypical bacterial pathogens, viral pathogens, and unknown pathogens. PCT cutoffs of $2 \mathrm{ng} / \mathrm{mL}$ accurately identified HAP children with typical bacterial pathogens. Our findings suggested that PCT may serve as a reliable biomarker for the early diagnosis and treatment indicator of children with HAP. This cohort study with 264 pediatric HAP patients demonstrated the reliability of PCT level as a biomarker in patients with typical bacterial pathogens. Specifically, PCT cutoffs of $2 \mathrm{ng} / \mathrm{mL}$ accurately identified HAP children with typical bacterial pathogens. These findings suggested that PCT may serve as a reliable biomarker for the early diagnosis and treatment indicator of children with HAP.

Funding The study was supported by the Cangzhou Science and Technology Research and Development Program (Grant No. cz151302039).

\section{Compliance with ethical standards}

Conflict of interest The authors declare that they have no conflict of interest.

Research involving human and/or animals participants Protocol was reviewed by Institutional Review Board and the Ethics Committee of the Cangzhou Central Hospital. All procedures performed in studies involving human participants were in accordance with the ethical standards of the institutional and/or national research committee and with the 1964 Helsinki declaration and its later amendments or comparable ethical standards.

Informed consent Informed consent was signed by the parents or guardians of each participant.

\section{References}

1. Burgos J, Falco V, Almirante B (2019) Chemical pharmacotherapy for hospital-acquired pneumonia in the elderly. Expert Opin Pharmacother 20:423-434. https://doi.org/10.1080/14656 566.2018.1559820

2. Hyvarinen M, Piippo-Savolainen E, Korhonen K, Korppi M (2005) Teenage asthma after severe infantile bronchiolitis or pneumonia. Acta Paediatr 94:1378-1383. https://doi. org/10.1111/j.1651-2227.2005.tb01807.x

3. Ogimi C, Shoji K, Katsuta T, Watanabe Y, Saitoh A (2012) Utility of gram stain of endotracheal aspirates on empiric therapy in children with hospital-acquired pneumonia. J Infect 65:368-370. https://doi.org/10.1016/j.jinf.2012.06.002

4. Fritz CQ, Edwards KM, Self WH, Grijalva CG, Zhu Y, Arnold SR, McCullers JA, Ampofo K, Pavia AT, Wunderink RG, Anderson EJ, Bramley AM, Jain S, Williams DJ (2019) Prevalence, risk factors, and outcomes of bacteremic pneumonia in children. Pediatrics. https://doi.org/10.1542/peds.2018-3090

5. Iroh Tam PY, Bernstein E, Ma X, Ferrieri P (2015) Blood culture in evaluation of pediatric community-acquired pneumonia: a systematic review and meta-analysis. Hosp Pediatr 5:324-336. https ://doi.org/10.1542/hpeds.2014-0138

6. Meisner M (2002) Pathobiochemistry and clinical use of procalcitonin. Clin Chim Acta 323:17-29

7. Mehanic S, Baljic R (2013) The importance of serum procalcitonin in diagnosis and treatment of serious bacterial infections and sepsis. Mater Sociomed 25:277-281. https://doi.org/10.5455/ msm.2013.25.277-281

8. Becker KL, Snider R, Nylen ES (2008) Procalcitonin assay in systemic inflammation, infection, and sepsis: clinical utility and limitations. Crit Care Med 36:941-952. https://doi.org/10.1097/ ccm.0b013e318165babb

9. Chua AP, Lee KH (2004) Procalcitonin in severe acute respiratory syndrome (SARS). J Infect 48:303-306. https://doi.org/10.1016/j. jinf.2004.01.015

10. Mitaka C (2005) Clinical laboratory differentiation of infectious versus non-infectious systemic inflammatory response syndrome. Clin Chim Acta 351:17-29. https://doi.org/10.1016/j. cccn.2004.08.018

11. Zhu F, Jiang Z, Li WH, Wei HY, Su GD (2015) Clinical significance of serum procalcitonin level monitoring on early diagnosis of severe pneumonia on children. Eur Rev Med Pharmacol Sci 19:4300-4303

12. Massaro KS, Costa SF, Leone C, Chamone DA (2007) Procalcitonin (PCT) and C-reactive protein (CRP) as severe systemic 
infection markers in febrile neutropenic adults. BMC Infect Dis 7:137. https://doi.org/10.1186/1471-2334-7-137

13. Christ-Crain M, Jaccard-Stolz D, Bingisser R, Gencay MM, Huber PR, Tamm M, Muller B (2004) Effect of procalcitonin-guided treatment on antibiotic use and outcome in lower respiratory tract infections: cluster-randomised, single-blinded intervention trial. Lancet 363:600-607. https://doi.org/10.1016/s0140 $-6736(04) 15591-8$

14. Di Pasquale M, Aliberti S, Mantero M, Bianchini S, Blasi F (2016) Non-intensive care unit acquired pneumonia: a new clinical entity? Int J Mol Sci 17:287. https://doi.org/10.3390/ijms1 7030287

15. Muller F, Christ-Crain M, Bregenzer T, Krause M, Zimmerli W, Mueller B, Schuetz P (2010) Procalcitonin levels predict bacteremia in patients with community-acquired pneumonia: a prospective cohort trial. Chest 138:121-129. https://doi.org/10.1378/chest .09-2920

16. Wiedermann FJ, Kaneider N, Egger P, Tiefenthaler W, Wiedermann CJ, Lindner KH, Schobersberger W (2002) Migration of human monocytes in response to procalcitonin. Crit Care Med 30:1112-1117

17. Julian-Jimenez A, Gutierrez-Martin P, Lizcano-Lizcano A, LopezGuerrero MA, Barroso-Manso A, Heredero-Galvez E (2015) Usefulness of procalcitonin and C-reactive protein for predicting bacteremia in urinary tract infections in the emergency department. Actas Urol Esp 39:502-510. https://doi.org/10.1016/j.acuro .2015.03.003

18. Schutzle H, Forster J, Superti-Furga A, Berner R (2009) Is serum procalcitonin a reliable diagnostic marker in children with acute respiratory tract infections? A retrospective analysis. Eur J Pediatr 168:1117-1124. https://doi.org/10.1007/s00431-008-0899-3

19. Becker KL, Nylen ES, White JC, Muller B, Snider RH Jr (2004) Clinical review 167: procalcitonin and the calcitonin gene family of peptides in inflammation, infection, and sepsis: a journey from calcitonin back to its precursors. J Clin Endocrinol Metab 89:1512-1525. https://doi.org/10.1210/jc.2002-021444

20. Korppi M, Remes S (2001) Serum procalcitonin in pneumococcal pneumonia in children. Eur Respir J 17:623-627

21. Korppi M, Don M, Valent F, Canciani M (2008) The value of clinical features in differentiating between viral, pneumococcal and atypical bacterial pneumonia in children. Acta Paediatr 97:943-947. https://doi.org/10.1111/j.1651-2227.2008.00789.x

22. Toikka P, Irjala K, Juven T, Virkki R, Mertsola J, Leinonen M, Ruuskanen O (2000) Serum procalcitonin, C-reactive protein and interleukin-6 for distinguishing bacterial and viral pneumonia in children. Pediatr Infect Dis J 19:598-602

23. Gilbert DN (2011) Procalcitonin as a biomarker in respiratory tract infection. Clin Infect Dis 52(Suppl 4):S346-350. https://doi. org/10.1093/cid/cir050

24. Park JH, Wee JH, Choi SP, Oh SH (2012) The value of procalcitonin level in community-acquired pneumonia in the ED. Am J Emerg Med 30:1248-1254. https://doi.org/10.1016/j. ajem.2011.08.009

25. Andrijevic I, Matijasevic J, Andrijevic L, Kovacevic T, Zaric B (2014) Interleukin-6 and procalcitonin as biomarkers in mortality prediction of hospitalized patients with community acquired pneumonia. Ann Thorac Med 9:162-167. https://doi. org/10.4103/1817-1737.134072

26. Kim MW, Lim JY, Oh SH (2017) Mortality prediction using serum biomarkers and various clinical risk scales in communityacquired pneumonia. Scand J Clin Lab Invest 77:486-492. https ://doi.org/10.1080/00365513.2017.1344298

Publisher's Note Springer Nature remains neutral with regard to jurisdictional claims in published maps and institutional affiliations. 